\title{
‡USGS
}

science for a changing world

Prepared in cooperation with the U.S. Fish and Wildlife Service

\section{Internal Nutrient Sources and Dissolved Nutrient Distributions in Alviso Pond A3W, California}

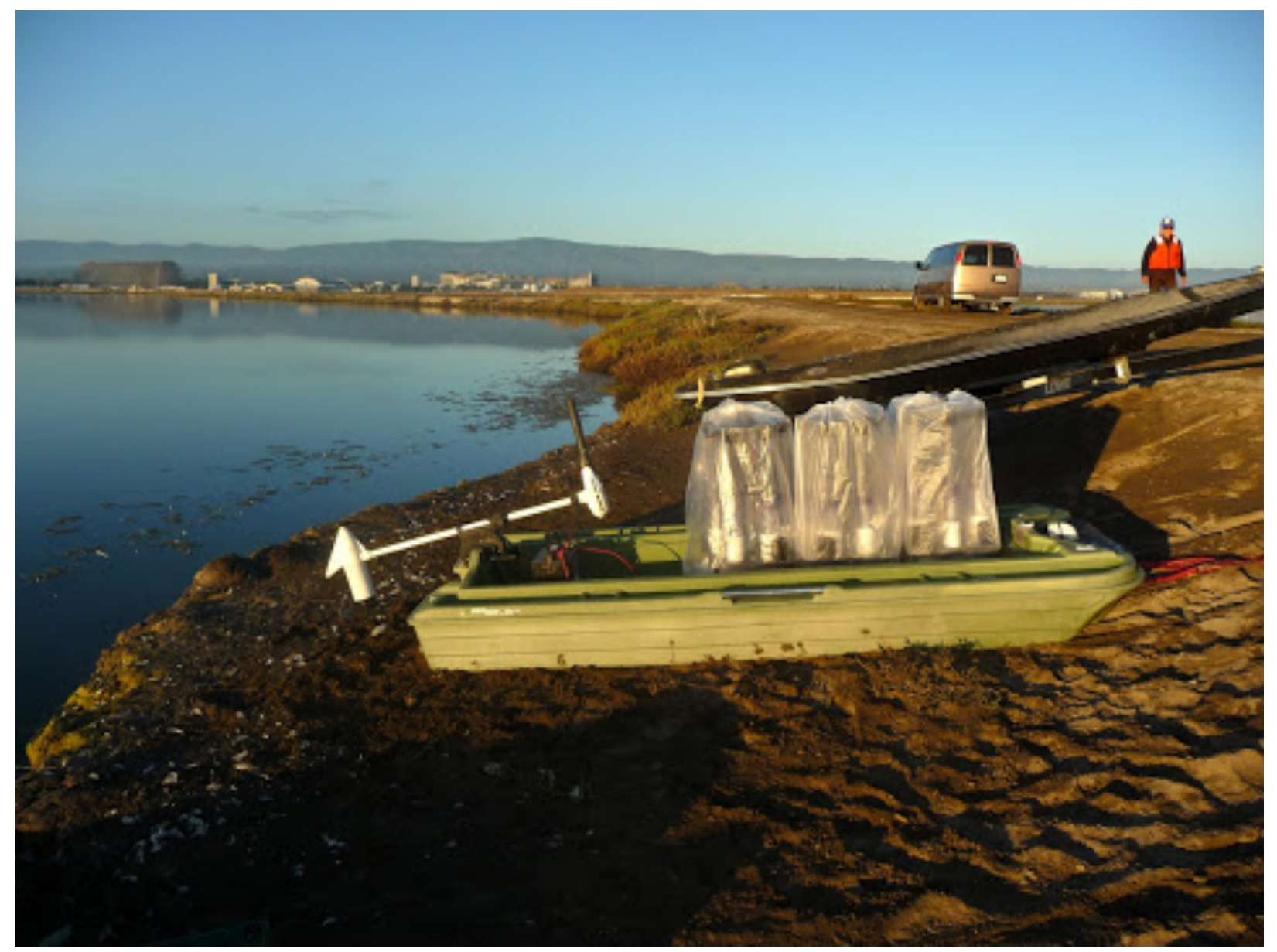

Open-File Report 2013-1128

U.S. Department of the Interior

U.S. Geological Survey 
COVER:

A motorized sea kayak on the shore of Alviso Pond A3W, California, with porewater profilers awaiting deployment (U.S. Geological Survey photograph by Iris Clearwater). 


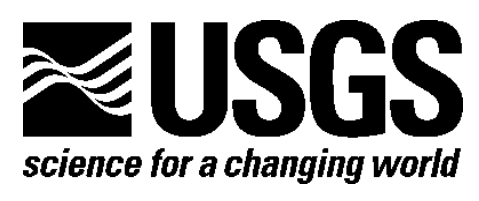

Prepared in cooperation with the U.S. Fish and Wildlife Service

\section{Internal Nutrient Sources and Dissolved Nutrient Distributions in Alviso Pond A3W, California}

By Brent R. Topping, James S. Kuwabara, Krista K. Garrett, John Y. Takekawa, Francis

Parchaso, Sara Piotter, Iris Clearwater, and Gregory G. Shellenbarger

Open-File Report 2013-1128

U.S. Department of the Interior

U.S. Geological Survey 


\section{U.S. Department of the Interior \\ SALLY JEWELL, Secretary}

\section{U.S. Geological Survey \\ Suzette M. Kimball, Acting Director}

U.S. Geological Survey, Reston, Virginia: 2013

its natural and living resources, natural hazards, and the environment-visit

http://www.usgs.gov or call 1-888-ASK-USGS

For an overview of USGS information products, including maps, imagery, and publications, visit $h$ ttp://www.usgs.gov/pubprod

To order this and other USGS information products, visit $h$ ttp://store.usgs.gov

Suggested citation:

Topping, B.R., Kuwabara, J.S., Garrett, K.K., Takekawa, J.Y., Parchaso, F., Piotter, S., Clearwater, I., and Shellenbarger, G.G., 2013, Internal nutrient sources and nutrient distributions in Alviso Pond A3W, California: U.S. Geological Survey Open-File Report 2013-1128, 17 p. and data tables, http://pubs.usgs.gov/of/2013/1128/.

Any use of trade, firm, or product names is for descriptive purposes only and does not imply endorsement by the U.S. Government.

Although this information product, for the most part, is in the public domain, it also may contain copyrighted materials as noted in the text. Permission to reproduce copyrighted items must be secured from the copyright owner. 


\section{Contents}

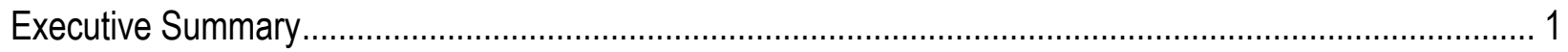

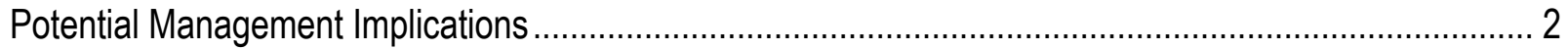

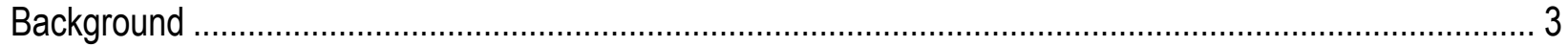

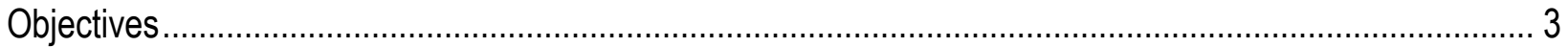

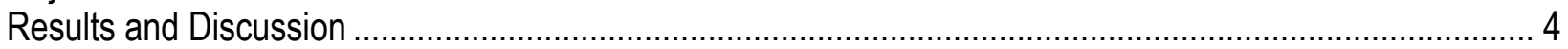

Initial Measurements of Benthic Nutrient Sources in Pond A3W (with comparisons to nutrient

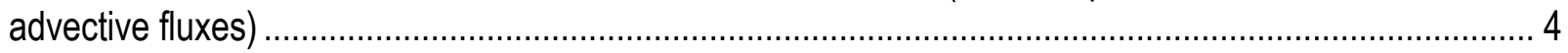

Macronutrient Distributions in the Water Column of Pond A3W (Weekly sampling frequency) .................. 5

Chlorophyll in the Water Column and Benthos of Pond A3W............................................................ 6

Methodological Comparison of Benthic Oxygen Demand ……......................................................... 7

Dissolved Organic Carbon (DOC) in the Water Column ................................................................... 7

Benthic Flux of Dissolved Metals for Pond A3W.................................................................... 8

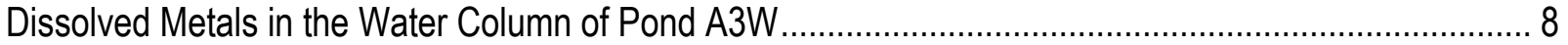

Study Design and Methods ................................................................................................... 9

Benthic-flux Measurements Based on Solute Diffusion .................................................................. 9

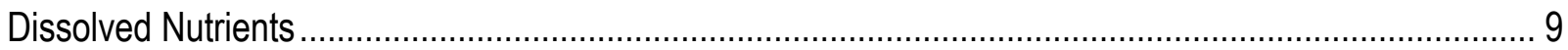

Chlorophyll Measurements ...................................................................................................... 9

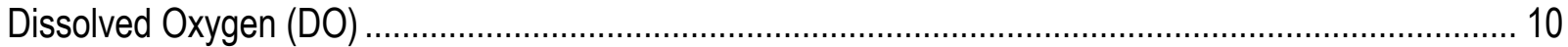

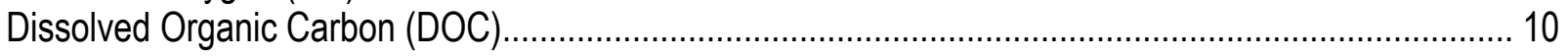

Dissolved Metals............................................................................................................... 10

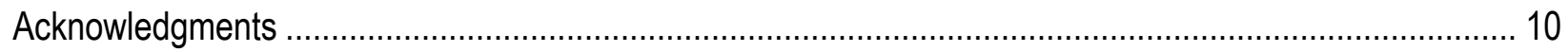

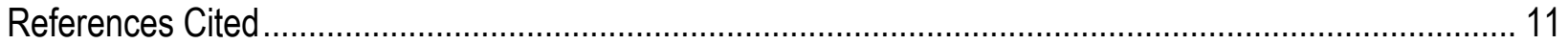

\section{Figures}

1. Satellite image of former salt ponds near Alviso, California, including flow direction between

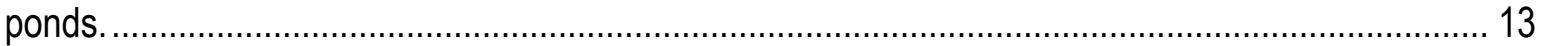

2. Satellite image of salt pond $A 3 W$ near Alviso, California, with sampling locations........................... 14

3. Plot of dissolved-oxygen in the water column for salt pond $A 3 W$ as monitored by dataloggers during June 27-28, 2012, pore-water sampling. ................................................................... 15

4. Plot of dissolved-oxygen in the water column for salt pond $A 3 W$ as monitored by dataloggers during August 8-9, 2012, pore-water sampling..................................................................... 16

5. Plot of dissolved-oxygen in the water column for salt pond $\mathrm{A} 3 \mathrm{~W}$ as monitored by dataloggers during October 2-3, 2012, pore-water sampling.

\section{Tables}

[Note that tables are provided online only as a .xlsx workbook at http://pubs.usgs.gov/of/2013/1128/]

1. Water-quality sites, salt pond $A 3 W$ near Alviso, California.

2. Dissolved macronutrient fluxes in 2010 and 2012 in salt pond $A 3 W$.

3. Weekly nutrient concentrations for 2010 in salt pond A3W.

4. Weekly nutrient concentrations for 2011 in salt pond A3W.

5. Weekly nutrient concentrations for 2012 in salt pond $A 3 W$.

6. Water-column chlorophyll and phaeophytin concentrations in salt pond A3W. 
7. Benthic chlorophyll and phaeophytin concentrations in salt pond A3W.

8. Summary of dissolved-oxygen diffusive fluxes for salt pond A3W.

9. Dissolved-oxygen-concentration (DOC) profiles and water-column DOC in salt pond A3W.

10. Dissolved metal fluxes in 2010 and 2012 in salt pond $A 3 W$.

11. Dissolved metal concentrations in weekly 2010 samples from salt pond $A 3 W$.

12. Dissolved metal concentrations in weekly 2011 samples from salt pond A3W.

13. Dissolved metal concentrations in weekly 2012 samples from salt pond A3W.

\section{Conversion Factors}

Inch/Pound to SI

\begin{tabular}{lll}
\hline \multicolumn{1}{c}{ Multiply } & \multicolumn{1}{c}{ By } & \multicolumn{1}{c}{ To obtain } \\
\hline & & \\
foot $(\mathrm{ft})$ & 0.3048 & meter $(\mathrm{m})$ \\
inch (in.) & 2.54 & centimeter $(\mathrm{cm})$ \\
micromoles $(\mu \mathrm{mol})$ & 1000 & millimoles $(\mathrm{mmol})$ \\
micromolar $(\mu M)$ & molecular weight & micrograms per liter $\left(\mu \mathrm{g}-\mathrm{L}^{-1}\right)$ \\
micrograms per liter $\left(\mu \mathrm{g}-\mathrm{L}^{-1}\right)$ & 0.001 & milligrams per liter $\left(\mathrm{mg}-\mathrm{L}^{-1}\right)$ \\
micrometer $(\mu \mathrm{m})$ & $1,000,000$ & meter $(\mathrm{m})$ \\
mile $(\mathrm{mi})$ & 1.609 & kilometer $(\mathrm{km})$ \\
& & \\
\hline
\end{tabular}

\section{Abbreviations and Acronyms}

DO

SRP

USFWS

USGS
Dissolved oxygen

Dissolved (soluble) reactive phosphate

U.S. Fish and Wildlife Service

U.S. Geological Survey 


\section{Internal Nutrient Sources and Nutrient Distributions in Alviso Pond A3W, California}

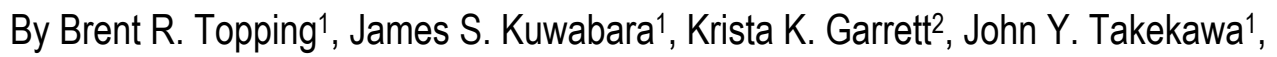
Francis Parchaso ${ }^{1}$, Sara Piotter ${ }^{1}$, and Gregory G. Shellenbarger ${ }^{1}$

\section{Executive Summary}

Within the Alviso Salt Pond complex, California, currently undergoing avian-habitat restoration, pore-water profilers (U.S. Patent 8,051,727 B1) were deployed in triplicate at two contrasting sites in Pond A3W ("Inlet", near the inflow, and "Deep", near the middle of the pond; figs. 1 and 2; table 1, note that tables in this report are provided online only as a .xlsx workbook at http://pubs.usgs.gov/of/2013/1128/). Deployments were conducted in 2010 and 2012 during the summer algal-growth season. Specifically, three deployments, each about 7 weeks apart, were undertaken each summer. This study provides the first measurements of the diffusive flux of nutrients across the interface between the pond bed and water column (that is, benthic nutrient flux). These nutrient fluxes are crucial to pond restoration efforts because they typically represent a major (if not the greatest) source of nutrients to the water column in both ponds and other lentic systems.

For soluble reactive phosphorus (SRP, the most biologically available form in solution), benthic flux was positive both years (that is, out of the sediment into the water column; table 2), with the exception of the August 2010 deployment, which exhibited nearly negligible but negative flux. Overall, the average SRP flux was significantly greater at Deep (23.9 \pm 8.6 micromoles per square meter per hour $\left(\mu \mathrm{mol}-\mathrm{m}^{-2}-\mathrm{h}^{-1}\right)$; all errors shown reflect the 95 -percent confidence interval) than Inlet $\left(12.6 \pm 4.9 \mu \mathrm{mol}-\mathrm{m}^{-2}-\mathrm{h}^{-1}\right)$. There was much greater temporal variability in SRP flux in the pond than reported for the lower estuary (Topping and others, 2001).

For dissolved ammonia, benthic flux was consistently positive on all six sampling trips, and similar to SRP, the fluxes at Deep $\left(258 \pm 49 \mu \mathrm{mol}-\mathrm{m}^{-2}-\mathrm{h}^{-1}\right)$ were consistently greater than those at Inlet $\left(28 \pm 11 \mu \mathrm{mol}-\mathrm{m}^{-2}-\mathrm{h}^{-1}\right)$. Dissolved ammonia fluxes reported for South San Francisco Bay by Topping and others (2001) fall in between these values. Once again, greater variability for benthic fluxes determined in the pond was observed relative to adjacent South San Francisco Bay. With the near absence of any measurable concentration gradient, dissolvednitrate fluxes were consistently negligible in the pond.

Silica fluxes are often used to represent sediment diagenetic processes that biogeochemically cycle silica (an important algal macronutrient) between biogenic and inorganic phases (Fanning and Pilson, 1974; Emerson and others, 1984). For South San Francisco Bay, those values are consistently positive from core-incubation experiments. In Pond A3W, dissolved-silica fluxes averaged $49 \pm 25 \mu \mathrm{mol}-\mathrm{m}^{-2}-\mathrm{h}^{-1}$ at Inlet and were much higher at Deep

\footnotetext{
${ }^{1}$ U.S. Geological Survey

${ }^{2}$ Whitman College, Walla Walla, Wash.
} 
$\left(482 \pm 370 \mu \mathrm{mol}-\mathrm{m}^{-2}-\mathrm{h}^{-1}\right)$, similar to the spatially variability observed for SRP and dissolved ammonia. An elevated silica flux can stimulate diatom production and subsequent eutrophication effects. Variability in these silica fluxes is consistent with season patterns in pond primary productivity.

On the basis of comparisons of dissolved-oxygen flux measurements by profilers and core incubations, it appears that diffusive flux estimates for the sediment in this pond, as one might expected in such benthically productive environments, result in a significant underestimation of true sediment oxygen demand. Therefore, a core incubation experiment was conducted to better quantify the demand.

To complement these benthic-flux studies, a diurnal study of nutrient advective flux into and out of the pond was measured during neap and spring tides to provide comparative estimates for allochthonous solute transport (Garret, 2012). Using the two different tides as the probable upper and lower boundaries, we can estimate a range of probable values throughout the year. After converting this advective flux into $\mathrm{kg} / \mathrm{yr}$, we can compare it directly to benthic flux estimates for the pond extrapolated over the 2.27 square kilometer $\left(\mathrm{km}^{2}\right)$ pond surface. Benthic flux of nitrogen species, averaged over all sites and dates, was about 80,000 kilograms per year $(\mathrm{kg} / \mathrm{yr})$, well above the adjective flux range of -50 to $1,500 \mathrm{~kg} / \mathrm{yr}$. By contrast, the average benthic flux of orthophosphate was about $12,000 \mathrm{~kg} / \mathrm{yr}$, well below the advective flux range of 21,500 to $30,000 \mathrm{~kg} / \mathrm{yr}$.

Initial benthic flux estimates were also made for trace metals, including copper, nickel, iron, and manganese. These analyses indicated that the two sites, Inlet and Deep, have different pore-water profiles, with Inlet exhibiting much higher benthic flux estimates for nickel, iron, and manganese.

These initial benthic-flux values reported for macronutrients are particularly impressive in magnitude when one considers that diffusive flux of dissolved solutes based on pore-water profiles provides a conservative determination that may be enhanced by other biogeochemical processes. These enhancement processes (Boudreau and Jorgensen, 2001) include bioturbation, bioirrigation, wind resuspension, and potential groundwater inflows, some of which are captured in core-incubation experiments (Kuwabara and others, 2009). Hence, the values reported herein represent lower bounds to indicate the potential importance of such internal solute sources. The elevated diffusive fluxes for nutrients in the pond relative to the adjacent estuary indicate that vertical nutrient transport between the pond bed and water column is consistently an important (and at times the most important) source of nutrients that stimulate phytoplankton growth in the water column. One might therefore reasonably hypothesize that this benthic transport of biologically reactive solutes (both nutrients and toxicants) represents the most important step at the base of the food web for trophic transfer.

\section{Potential Management Implications}

Benthic flux is largely generated by natural and anthropogenic processes that accumulate surface-reactive solutes (that is, certain organic and inorganic nutrients and toxicants) in bed sediment over annual to decadal time scales. It is likely that long-term improvements in water quality within the pond will eventually lead to decreases in contaminant pore-water gradients. However, such decreases are expected to lag in both time and magnitude relative to any surfacewater regulatory improvements. This is because the decades-long accumulation of solutes with the sediments will continue to generate a benthic flux until either the solutes diffuse completely into the water column or new sediment lacking the solutes settles sufficiently to diminish the gradient at the sediment-water interface. 
There are engineering steps that could be taken to help mitigate the dissolved-oxygen (DO) depletion. Managers could mechanically aerate waters at the pond outflow during low-DO summer periods so that advective transport through the pond could be maximized without compromising receiving water quality. Similarly, if flows can be managed according to diurnal patterns, it would be useful to maximize flow during the day (that is, high DO periods), while also mechanically aerating the pond water column at the inflow and outflow during the night. Inflow water can also be baffled to create turbulence near the inflow, outflow, or both to increase atmospheric oxygen diffusion (that is, increased surface area and mixing).

\section{Background}

With the implementation of the South Bay Restoration Program in 2004, water quality in the Alviso Salt Ponds has been monitored to document the effects of changing hydrologic connections among the ponds and the adjacent estuary (Life Science, Inc., 2003). Such waterquality monitoring provides managers with confirmation or the necessary feedback to understand the ability of these evolving ecosystems to support the biological resources, such as desired terrestrial-wildlife, water-column, and benthic communities. To complement this ongoing watercolumn monitoring in the ponds, pore-water profilers were deployed in 2008 (data published in Topping and others, 2009), 2010, and 2012 to provide the first and only measurements of oxygen, macronutrient, micronutrient, trace metal, and dissolved organic-carbon fluxes across the sediment-water interface associated with the pond benthos. These measurements are critical to pond restoration because they quantify a major, but often neglected, nutrient source available to the base of the pond food web. That food-web base also represents the first and often the highest most exponential step of biological accumulation for particle reactive solutes (for example mercury, certain macronutrients, herbicides, and pharmaceuticals).

Furthermore, anoxic waters, consistently near the sediment-water interface (Topping and others, 2009), are unsuitable for survival of many aquatic organisms spanning all trophic levels, and can lead to massive fish die-offs. Studies presented herein can help to quantify the dissolvedoxygen demand in the system, as well as estimate the sources of nutrients that will continue to fuel primary production and eventually algal degradation by respiring bacteria.

\section{Objectives}

This study provides initial measurements of nutrient benthic flux that complement ongoing investigations of allochthonous solute transport through salt ponds undergoing habitat restoration. In addition, the importance of these benthic nutrient exchanges is quantified over multiple spatial and temporal scales, which provide an important contribution to science-based management and monitoring guidance. This work extends the studies of sediment oxygen demand in these salt ponds and fills a major gap by quantifying nutrient sources that drive the base of the food web in these ponds and hence the base of trophic transfer for toxic solutes like mercury.

It is reasonable to hypothesize that the redox gradients generated by oxygen depletion, observed at A3W in 2008 and 2010 (oxygen flux analysis was not done in 2012) may alter the mobility of surface reactive nutrients (both essential and toxic metals and ligands). However, there are no other measurements are currently available to quantitatively describe internal sources (benthic fluxes) of these biologically reactive solutes in these ponds. This information gap, crucial to phytoplankton and food-web dynamics in the ponds, was addressed by this study and is presented herein, completing a 2-year study. We also addressed some fundamental questions about nutrient dynamics in the ponds, responding to flow management: 
1. Are benthic sources of nutrients (including trace metals that serve as micronutrients) to the pond water column significant relative to advective transport into and out of the ponds through weirs and breaches? How do those sources vary during the summer period of elevated primary productivity in the ponds?

2. Do benthic sources of nutrients favor certain primary producers (for example, cyanophytes (cyanobacteria)) over bacillariophytes (diatoms) based on concentration ratios?

3. Can diffusive and advective fluxes of nutrients account for the overall balance of biomass generated in these ponds?

\section{Results and Discussion}

\section{Initial Measurements of Benthic Nutrient Sources in Pond A3W (With Comparisons to Nutrient Advective Fluxes)}

On June 30, August 18, and September 21, 2010, and on June 27, August 8, and October 2, 2012, pore-water profilers (U.S. Patent 8,051,727 B1; Kuwabara and others, 2007) were deployed in triplicate at two contrasting sites in Pond A3W ("Inlet", near the inflow, and "Deep", near the middle of the pond) to provide the first measurements of the diffusive flux of nutrients across the interface between the pond bed and water column (that is, benthic nutrient flux). Understanding these fluxes are crucial to pond restoration efforts because they typically represent a major (if not the largest) source of nutrients to the water column for ponds and other lentic systems. Measurements of benthic flux described herein assume that molecular diffusion regulates the transport of solutes across that interface. Given that other processes (bioturbation, bioirrigation) may enhance diffusive flux (Kuwabara and others, 2009), these measurements provide only a conservative estimate of the relative importance of benthic flux as a nutrient source. For soluble reactive phosphorus (SRP, the most biologically available form in solution), benthic flux was positive (that is, out of the sediment into the water column) for five of the six sampling dates and near zero for the outlier (August 2010; table 2). It is possible that in August 2010 the near zero values were due to intense primary productivity depleting benthic sources. However, this pattern was not repeated in August 2012, which exhibited the highest values observed for Inlet in either year $\left(28.7 \pm 14.4 \mu \mathrm{mol}-\mathrm{m}^{-2}-\mathrm{h}^{-1}\right.$; all errors shown reflect the 95-percent confidence interval). The averaged values are greater at Deep than Inlet for four of the five positive flux events, with August 2012 being the outlier. The average of all six dates yields greater values at Deep $\left(23.9 \pm 8.6 \mu \mathrm{mol}-\mathrm{m}^{-2}-\mathrm{h}^{-1}\right)$ than at Inlet $\left(12.6 \pm 4.9 \mu \mathrm{mol}-\mathrm{m}^{-2}-\mathrm{h}^{-1}\right)$. In the adjacent estuary, Topping and others (2001) reported consistently positive SRP benthic fluxes for South San Francisco Bay ranging from 2.3 to $6.8 \mu \mathrm{mol}-\mathrm{m}^{-2}-\mathrm{h}^{-1}$ using core-incubation measurements that incorporate bioturbation and bioirrigation effects. There was much greater temporal variability in SRP flux in the pond, seen at both sites, between and within years, than reported for the lower estuary.

For dissolved ammonia, benthic flux was consistently positive on all six sampling trips, and similar to SRP, the average fluxes at Deep $\left(258 \pm 49 \mu \mathrm{mol}-\mathrm{m}^{-2}-\mathrm{h}^{-1}\right)$ were consistently greater than those at Inlet $\left(28 \pm 11 \mu \mathrm{mol}-\mathrm{m}^{-2}-\mathrm{h}^{-1}\right)$. The ammonia flux for Deep, calculated only from diffusion, far exceeds those reported for South San Francisco Bay by Topping and others (2001) for dissolved ammonia (range of 15 to $92 \mu \mathrm{mol}-\mathrm{m}^{-2}-\mathrm{h}^{-1}$ ), using a core incubation method. 
With the absence of any measurable concentration gradient, dissolved-nitrate fluxes were consistently negligible $\left(<0.2 \mu \mathrm{mol}-\mathrm{m}^{-2}-\mathrm{h}^{-1}\right)$ in the pond. In contrast, consistently positive nitrate fluxes have been previously reported for South San Francisco Bay (Topping and others 2001).

Silica fluxes are often used to represent sediment diagenetic processes that biogeochemically cycle silica (an important algal macronutrient) between biogenic and inorganic phases (Fanning and Pilson, 1974; Emerson and others, 1984), and for South San Francisco Bay, those values are consistently positive from core-incubation experiments (ranged of 75 to 294 $\mu \mathrm{mol}-\mathrm{m}^{-2}-\mathrm{h}^{-1}$; Topping and others, 2001). In Pond A3W, dissolved-silica fluxes ranged from 10 \pm 12 to $193+83 \mu \mathrm{mol}-\mathrm{m}^{-2}-\mathrm{h}^{-1}$ at Inlet and were higher at Deep with a range of $98 \pm 48$ to $862 \pm$ $466 \mu \mathrm{mol}-\mathrm{m}^{-2}-\mathrm{h}^{-1}$, similar to the spatial variability observed for SRP and dissolved ammonia. An elevated silica flux can stimulate diatom production and subsequent eutrophication effects. Variability in these silica fluxes was consistent with seasonal patterns in pond primary productivity.

In summary, the initial macronutrient benthic-flux values in Pond A3W are particularly impressive in magnitude, especially considering that diffusive flux of dissolved solutes based on pore-water profiles provides a conservative determination, one that may be enhanced by other biogeochemical processes. These enhancement processes include bioturbation, bioirrigation, wind resuspension, and potential groundwater inflows, some of which are captured in coreincubation experiments (Kuwabara and others, 2009, Berelson and others, 2003). Hence, the values reported herein represent lower bounds to indicate the potential importance of such internal solute sources. The elevated diffusive fluxes for nutrients in the pond relative to the adjacent estuary indicate that vertical nutrient transport between the pond bed and water column is consistently an important (and in some years the most important) source of nutrients that stimulate phytoplankton growth in the water column. These results suggest that the benthic transport of biologically reactive solutes (both nutrients and toxicants) represents an important first step in contributing to the trophic transfer of biomagnifying solutes like mercury.

\section{Macronutrient Distributions in the Water Column of Pond A3W (Weekly Sampling Frequency)}

In addition to benthic-flux measurements for nutrients, weekly samples of the upper water column ( 0.5 meter, $\mathrm{m}$, depth) were also taken from early summer through mid-autumn in pond $\mathrm{A} 3 \mathrm{~W}$ in 2010, 2011, and 2012 (tables 3, 4, and 5). Inlet, as well as a site near the outflow of the pond (hereafter referred to as "Discharge"), were sampled weekly in all years. Another site, "Shallow \#2", was sampled in 2010 and 2012, whereas two additional sites, "Algal" (near an algal mat) and the previously mentioned "Deep" were also sampled in 2010 only. Because the pond's major inflow occurs at Inlet, and the sole outflow occurs at Discharge, comparing concentrations of nutrients at these sites on the same dates suggest nutrient sources and losses in the pond (part of a potential "nutrient budget" calculation). In other words, the difference will indicate whether nutrients increased or decreased while the water flows through the pond. For ammonia, Discharge was 0.1 milligrams per liter $(\mathrm{mg} / \mathrm{L})$ higher, on average, than Inlet. For nitrate, Discharge was $0.3 \mathrm{mg} / \mathrm{L}$ higher, on average, than Inlet. For silica, Discharge was 4.0 $\mathrm{mg} / \mathrm{L}$ higher, on average, than Inlet. Lastly, for SRP, Discharge was $0.2 \mathrm{mg} / \mathrm{L}$ lower, on average, than Inlet. These data suggest that the pond as a whole acts as a net source of ammonia, nitrate, and silica to the water passing through and as a net sink for SRP.

These two observations are counterintuitive given that the nitrogen-phosphorous (N:P) molar ratio is $1.1 \pm 0.6$ for the 140 samples. For reference, the molar ratio of $\mathrm{N}: \mathrm{P}$ in phytoplankton is approximately $16: 1$. The ratio of $1.1 \pm 0.6$ for the pond is about 15 times lower, 
which indicates there is an abundance of $\mathrm{P}$ relative to $\mathrm{N}$. Because the shallow depth of the pond likely rules out light-limitation, this low ratio suggests N-limitation of primary productivity. Both the southern and northern regions of San Francisco Bay also exhibit this pattern. However, if the algal community is dominated by nitrogen-fixing (able to sequester nitrogen from atmospheric $\mathrm{N}_{2}$ ) cyanobacterium, $\mathrm{N}$ would not be considered the limiting nutrient. The algal community has not been identified at this time.

In 2012, ammonia concentrations at Inlet and Shallow \#2 diminished to less than 50 micrograms per liter $\left(\mu \mathrm{g}-\mathrm{L}^{-1}\right)$ starting in early July (table 5). The chlorophyll concentration in the water column increased monotonically throughout this period (table 6), suggesting that low $\mathrm{N}$ concentrations were not limiting algal growth. This pattern did not occur in 2011 (table 4), when ammonia concentrations never dropped below $50 \mu \mathrm{g}-\mathrm{L}^{-1}$. However, the lowest ammonia values at Discharge are coincident with the highest weekly chlorophyll measurements (table 6), which occurred in October 2011.

As Topping and others (2009) indicated, autotrophic activity in the Alviso Salt ponds generates centimeters-thick, benthic mats of algal biomass. Upon degradation, that biomass creates a benthic oxygen demand. This primary production assimilates macronutrients at a ratio referred to as the Redfield ratio (Wetzel, 2001). Specifically, dissolved inorganic nitrogen (nitrate, nitrite, and ammonium combined; $\mathrm{N}$ ) divided by dissolved phosphorus ( $\mathrm{P}$, most bioavailable as orthophosphate or soluble reactive phosphorus) often exists at the ratio of approximately 16:1 (in molar units) in systems without $\mathrm{N}$ or $\mathrm{P}$ limitation. Topping and others (2009) reported an average molar N:P in three Alviso Salt ponds of about 2:1 (27 \pm 24 micromolar N: $15 \pm 6$ micromolar P; Mruz and others, 2009), suggesting depleted nitrogen relative to phosphorous. However, while the ratio suggests $\mathrm{N}$ limitation, $\mathrm{N}$ concentrations remain well above detection limits, and thus are likely not limiting. This suggests that nitrogen-fixing cyanobacteria (blue-green algae) might thrive in the ponds, as evidenced by the presence of Anabaenopsis sp. and Anabaean sp. (Thebault and others, 2008).

\section{Chlorophyll in the Water Column and Benthos of Pond A3W}

During all six of the deployments of pore-water profilers, water-column and benthic chlorophyll samples were also taken (table 7). Benthic chlorophyll is an indicator of settled algal material which that may still be photosynthetically active, but may also consist of organic material being degraded by bacteria. This bacterial degradation consumes oxygen through respiration. Benthic chlorophyll was highest at both the Inlet and Deep sites on June 30, 2010 (9.5 and 8.3 micrograms per centimeter squared, $\mu \mathrm{g}-\mathrm{cm}^{-2}$, respectively; table 7 ) and much lower on Sept 21, 2010 (2.6 and $1.0 \mu \mathrm{g}-\mathrm{cm}^{-2}$, respectively). For Inlet, this pattern was repeated in 2012 $\left(24.0 \mu \mathrm{g}-\mathrm{cm}^{-2}\right.$ on June 27, 2012, and $3.1 \mu \mathrm{g}-\mathrm{cm}^{-2}$ on October 2, 2012). For Deep in 2012, it was less dramatic $\left(13.4 \mu \mathrm{g}-\mathrm{cm}^{-2}\right.$ on June 27,2012 , and $9.2 \mu \mathrm{g}-\mathrm{cm}^{-2}$ on October 2,2012$)$ but had a particularly high value on August 8, $2012\left(41.4 \mu \mathrm{g}-\mathrm{cm}^{-2}\right)$.

In the water column, chlorophyll concentrations exhibited a dramatic increase as the season progressed in all years. In 2010, the sampling frequency was low, but it included good spatial coverage with five sites. Chlorophyll data concentrations ranged from 4.6 to $14.7 \mu \mathrm{g}-\mathrm{L}^{-1}$ on June 30, 2010, from 9.8 to $18.9 \mu \mathrm{g}-\mathrm{L}^{-1}$ on August 18, 2010, and from 46.6 to $197.7 \mu \mathrm{g}-\mathrm{L}^{-1}$ on September 21, 2010 (table 6). Weekly sampling in 2011 and 2012 showed this the same pattern, albeit with more temporal resolution. In 2011, at the Discharge site, consistently low values were seen from July 14 to September 12, 2011, (average of $5.9 \mu \mathrm{g}-\mathrm{L}^{-1}$ ), followed by an apparent bloom with values peaking on October 17, 2011, at $132.7 \mu \mathrm{g}-\mathrm{L}^{-1}$. In 2012, a similar pattern appeared at all three sites sampled, but with an earlier apparent bloom. From June 12 to July 17, 
2012, all three sites averaged $7.7 \mu \mathrm{g}-\mathrm{L}^{-1}$ of water-column chlorophyll. Values rose quickly at all sites, peaking on September 4, 2012, and then maintaining relatively high values for the remainder of the sampling period. In fact, the highest value for Inlet was seen on October 2, 2012. If the timing of large bloom periods can be identified, the subsequent crash can be monitored for likely depletion of the oxygen in the water column. This may help identify when anoxic conditions could be present or threatening, and could allow managers to attempt to prevent fish kills.

\section{Methodological Comparison of Benthic Oxygen Demand}

Topping and others (2009) measured diffusive oxygen flux of $-1.33 \mu \mathrm{mol}-\mathrm{m}^{-2}-\mathrm{h}^{-1}$ (the negative value indicates oxygen consumption by the sediment) at the Inlet site in $\mathrm{A} 3 \mathrm{~W}$ and suggested that this was likely an underestimate due to other processes (for example, bioturbation, bioirrigation, and wind mixing) that enhance diffuse flux. In 2010, diffusive flux measurements were again made using the same pore-water profilers, while sediment oxygen demand (SOD) experiments using core incubations were performed concurrently. The diffusive flux estimates averaged $-0.39 \pm 0.66 \mathrm{mmol}-\mathrm{m}^{-2}-\mathrm{h}^{-1}$ over all sites and dates, whereas core-incubation measurements yielded an average of $-6.63 \pm 0.42 \mathrm{mmol}-\mathrm{m}^{-2}-\mathrm{h}^{-1}$ over all sites and dates (table 8). Topping and others (2004) reported similar SOD measurements for South San Francisco Bay ($2.5 \pm 2.3$ to $-5.0 \pm 2.4 \mathrm{mmol}-\mathrm{m}^{-2}-\mathrm{h}^{-1}$ ) from similar core-incubation experiments. It appears that for this sediment, diffusive flux estimates, as expected, result in a significant underestimation of true sediment oxygen demand.

Using the estimated pond surface area of 2.27 square kilometers, $-6.63 \mathrm{mmol}-\mathrm{m}^{-2}-\mathrm{h}^{-1}$ can be converted to $-5,780 \mathrm{~kg} /$ day. In Topping and others (2009), estimates of oxygen diffusion from the atmosphere into the pond were calculated. For A $3 \mathrm{~W}$, the average estimate was $1,630 \mathrm{~kg} /$ day. Comparing this value of $1,630 \mathrm{~kg}$ of oxygen each day diffusing into the water each day to the $5,780 \mathrm{~kg}$ we estimate is being consumed by the sediment each day, it is clear that oxygen depletion is likely in the water column. Photosynthetic oxygen production during the daytime likely mitigates the depletion, but during the night, the combination of sediment oxygen demand and algal respiration causes regular depletion. Figures in Topping and others (2009) also support this regular diurnal fluctuation. In-situ probe data for dissolved oxygen during pore-water sampling events in 2012 continues to exhibit this pattern, especially for Inlet (figs. 3, 4, and 5). At Deep, in August and October, photosynthetic activity appears unable cannot compensate overcome bacterial consumption, even in the middle of the day. Tide data is included to demonstrate that the peaks in oxygen correspond to the time of day (sunlight) and not to the flow of oxygenated water from the slough (figs. 3, 4, and 5).

\section{Dissolved Organic Carbon (DOC) in the Water Column}

Dissolved organic matter, measured as DOC, is a ligand that can compete for trace-metal complexation in the water and hence affect the remobilization and bioavailability of biologically reactive trace metals (Kuwabara and others, 1986). For example, Kuwabara and others (1989, 2002) noted that spatial trends for certain dissolved trace metals (copper and zinc) in South San Francisco Bay and Lahontan Reservoir (mercury) were coincident with DOC.

Profiler data for the DOC analysis on all pore waters was completed. The profiler data (table 9) exhibited increasing DOC concentrations increasing with depth, in some cases by an order of magnitude (table 9). These DOC concentration gradients indicate that organics are diffusing out of the sediment. Both the nearby Alviso Slough (Marvin-DiPasquale and Cox, 2007) and the upstream reservoirs (Kuwabara and others, 2005) are known to exhibit elevated 
mercury concentrations, and this mercury is likely to be bound to the organics diffusing out of the sediment. Future direct measurements of mercury in pore water would be required to investigate that possibility.

Water-column DOC concentrations ranged between 8 and 14 milligrams of carbon per liter (table 9), which is much higher than the typical South Bay concentrations of between 1 and $2 \mu \mathrm{g}-\mathrm{L}^{-1}$ reported elsewhere (Topping and others, 2004).

\section{Benthic Flux of Dissolved Metals for Pond A3W}

Just as this study provided the first macronutrient flux estimates for pond A3W, it also produced the first trace-metal flux calculations. On the schedule, and from the same sampling syringe, aliquots were acidified and analyzed for trace metals including copper, nickel, iron, manganese, cadmium, lead, vanadium, and zinc. Using Fick's Law, as described in Methods below, estimates of benthic flux from the sediment into the water column of $\mathrm{A} 3 \mathrm{~W}$ were generated.

Copper and nickel have been studied in South San Francisco Bay because of concerns about concentration levels approaching site-specific maximums (Buck and others, 2007). In A3W, during the 6 sampling dates in 2010 and 2012, copper fluxes averaged $2.1 \pm 1.9 \mu$ mol-m ${ }^{-2}$ $\mathrm{h}^{-1}$ at Inlet and $1.5 \pm 1.9 \mu \mathrm{mol}-\mathrm{m}^{-2}-\mathrm{h}^{-1}$ at Discharge, with relatively narrow ranges $(-0.7$ to 7.1 $\mu \mathrm{mol}-\mathrm{m}^{-2}-\mathrm{h}^{-1}$ at Inlet and -2.5 to $16.7 \mu$ mol $-\mathrm{m}^{-2}-\mathrm{h}^{-1}$ at Discharge; table 10). Nickel fluxes, by contrast, averaged 10.6 $\pm 12.1 \mu \mathrm{mol}-\mathrm{m}^{-2}-\mathrm{h}^{-1}$ at Inlet and $2.9 \pm 3.8 \mu \mathrm{mol}-\mathrm{m}^{-2}-\mathrm{h}^{-1}$ at Discharge, despite comparable ranges among the individual samples $\left(-0.4\right.$ to $43.2 \mu \mathrm{mol}-\mathrm{m}^{-2}-\mathrm{h}^{-1}$ at Inlet and 3.5 to $30.0 \mu \mathrm{mol}-\mathrm{m}^{-2}-\mathrm{h}^{-1}$ at Discharge).

Iron and manganese both form oxides under oxic conditions and are present as dissolved ions under anoxic conditions. Within many systems, the anoxic pore water a few centimeters below the surface can be highly concentrated in dissolved iron and manganese, whereas the oxidized surface water may not be. On diffusing into the water column, this aqueous iron and manganese will often form oxides and precipitate out of solution. In A3W, iron fluxes averaged $72 \pm 103 \mu \mathrm{mol}-\mathrm{m}^{-2}-\mathrm{h}^{-1}$ at Inlet and $19 \pm 12 \mu \mathrm{mol}-\mathrm{m}^{-2}-\mathrm{h}^{-1}$ at Discharge, with the large Inlet error being due to the dynamic range of values $\left(<4\right.$ to $766 \mu$ mol- $\mathrm{m}^{-2}-\mathrm{h}^{-1}$ at Inlet and -23 to $100 \mu \mathrm{mol}-$ $\mathrm{m}^{-2}-\mathrm{h}^{-1}$ at Discharge; table 10). Manganese fluxes were much higher (note the three orders of magnitude unit change), averaging $4.4 \pm 7.7 \mathrm{mmol}-\mathrm{m}^{-2}-\mathrm{h}^{-1}$ at Inlet and $1.3 \pm 1.9 \mathrm{mmol}-\mathrm{m}^{-2}-\mathrm{h}^{-1}$ at Discharge, and exhibiting a wide range $\left(0.0\right.$ to $29.2 \mathrm{mmol}-\mathrm{m}^{-2}-\mathrm{h}^{-1}$ at Inlet and 0.0 to $7.5 \mu \mathrm{mol}-\mathrm{m}^{-}$ ${ }^{2}-\mathrm{h}^{-1}$ at Discharge). Again, due to the oxidation/precipitation reactions for these elements, these fluxes may overestimate the movement of dissolved iron and manganese into the water column. None of the other elements (cadmium, lead, vanadium, and zinc) had significant or measureable benthic fluxes.

\section{Dissolved Metals in the Water Column of Pond A3W}

From the weekly samples discussed in the section "Macronutrient Distributions in the Water Column," aliquots were also taken for trace metals and analyzed as described in Methods. Copper concentrations over all sites and about 15 sampling events each year for 3 years (20102012) average close to $1 \mu \mathrm{g}-\mathrm{L}^{-1}$ with the highest sample at $2.7 \mu \mathrm{g}-\mathrm{L}^{-1}$ (tables 11,12 , and 13). Nickel concentrations, although higher, still fall well below the site-specific objectives for southern San Francisco Bay (11.9 $\mu \mathrm{g}-\mathrm{L}^{-1}$ average over 4 days). They averaged close to $2 \mu \mathrm{g}-\mathrm{L}^{-1}$, with the highest sample at $4.4 \mu \mathrm{g}-\mathrm{L}^{-1}$.

During blooms, the algal cells use iron as part of their growth. In the open ocean, iron can be the limiting nutrient for a bloom. This does not appear to be the case in A3W. During the 
bloom peaks in 2011 and 2012 (table 6), iron concentrations were still elevated, not depleted as would be expected for a limiting nutrient (tables 12 and 13; comparison can't be made for 2010 due to infrequent water-column sampling).

\section{Study Design and Methods}

Sampling and analytical methods for the proposed work are briefly described and referenced below. At each site, the following samples were collected, unless otherwise noted.

\section{Benthic-flux Measurements Based on Solute Diffusion}

A nonmetallic pore-water profiler (U.S. Patent 8,051,727 B1) was used to determine a vertical concentration gradient near the sediment-water interface, from which a diffusive solute flux was determined using Fick's Law (Kuwabara and others, 2009; Topping and others, 2009). The benthic flux ( $\mathrm{J}_{\mathrm{i}}$ in units of micromoles of solute i per square meter per hour), assuming diffusion-controlled transport (that is, a conservative estimate) may be calculated by the equation:

$\mathrm{J}_{\mathrm{i}}=\mathrm{D}_{\mathrm{i}, \mathrm{T}}(\varphi)(\mathrm{dC} / \mathrm{dz})$,

where

$\mathrm{D}_{\mathrm{i}, \mathrm{T}}$ is the diffusion coefficient of solute $\mathrm{i}$ at temperature $\mathrm{T}$ in units of centimeter squared per second,

$\varphi$ is the sediment porosity in dimensionless units, and

$\mathrm{dC}_{\mathrm{i}} / \mathrm{dz}$ is the concentration gradient for solute $\mathrm{i}$ in the vertical (or $\mathrm{z}$ ) direction in units of micrograms per liter per centimeter, and calculated flux values are converted to meter and hour units.

Flux calculations, based on Fick's Law, assume that the process is diffusion controlled with solute-specific diffusion coefficients (Li and Gregory, 1974). Hence, the calculated benthic flux of dissolved solutes based on pore-water profiles can be enhanced by bioturbation, bioirrigation, wind resuspension, and potential groundwater inflows.

At each profiler-deployment site, dataloggers monitored diel changes in the water column at 15-minute intervals. Samples for benthic chlorophyll- $a$ were also obtained by subcoring replicate grab samples.

In addition to profiler deployments, sediment oxygen demand (that is, benthic flux of dissolved oxygen) was determined by core incubations. Acrylic tubes were used to sample sediment cores, approximately $10 \mathrm{~cm}$ deep, from which overlying water was iteratively sampled and analyzed for dissolved oxygen (Topping and others 2004).

\section{Dissolved Nutrients}

Dissolved (0.2-micrometer, $\mu \mathrm{m}$, filtered) nutrient concentrations in both water-column and pore-water samples were determined by low-volume, batch-spectrophotometric methods (Kuwabara and others, 2009).

\section{Chlorophyll Measurements}

Water-column samples were taken just below the surface and collected onto glass-fiber filters, and analyzed by fluorometry (Parsons and others, 1984).

For benthic-chlorophyll measurements, surficial sediment (that is, the top $0.5 \mathrm{~cm}$ of bed material) was collected from each site using an Ekman grab and stored refrigerated in a plastic Petri dish within a sealed plastic bag. Each dish was subsampled in triplicate within 24 hours for benthic chlorophyll- $a$. The surficial sediment for each replicate was collected on a glass-fiber filter and buffered with 1 milliliter $(\mathrm{mL})$ of a magnesium carbonate suspension (10 grams per 
liter, $\mathrm{g} / \mathrm{L}$ ). Water was removed from the buffered samples by vacuum at less than 5 pounds per square inch to avoid cell lysis. Samples were then frozen in darkness for preservation until spectrophotometrically analyzed by methods described in Thompson and others (1981) and Franson (1985).

\section{Dissolved Oxygen (DO)}

Within hours of recovering the samplers, each $25-\mathrm{mL}$ glass syringe was placed in a syringe pump, which dispensed the sample at a steady rate. Dissolved oxygen ( 0.2 micron) was measured as the sample passed through a $3.2 \mathrm{~mL}(1 / 8 \mathrm{inch})$ acrylic $0.9-\mathrm{mL}$ flow-through cell fitted with a microelectrode (Microelectrodes, Inc., Bedford, New Hampshire). The microelectrode was calibrated initially with helium-sparged water and sloped with air-saturated water. Periodic calibration checks were performed using oxygen-free helium and air in place of water. Less than $1 \mathrm{~mL}$ of sample from the profiler syringe was required for a stable DO reading (Topping and others 2009). Until analysis, samples were contained within the glass syringes of the pore-water profiler.

\section{Dissolved Organic Carbon (DOC)}

Aliquots of sample water from the profiler syringes were dispensed directly into autosampler vials for dissolved organic-carbon analysis by high-temperature combustion (Qian and Mopper, 1996; Vandenbruwane and others, 2007). Potassium phthalate was used as the standard. Low-DOC water (blanks less than 40 micrograms organic $\mathrm{C}$ per liter) was generated from a double-deionization unit with additional ultraviolet treatment (Milli-Q Gradient, Millipore Corporation).

\section{Dissolved Metals}

Dissolved (0.2- $\mu \mathrm{m}$ filtered) metal concentrations in both water-column and pore-water samples were determined by flow-injection, inductively-coupled plasma mass spectrometry (FIICP-MS; Kuwabara and others, 2009).

Water-column samples were collected in duplicate in 250-mL acid-washed high-density polyethylene bottles, filtered $(0.2-\mu \mathrm{m}$ polycarbonate membrane), and acidified $(\mathrm{pH} 2)$ to provide dissolved trace-metal information for the saline waters by flow-injection (metals collected on an iminodiacetate chelating resin before analysis) inductively coupled plasma mass spectrometry (ICP-MS; Topping and Kuwabara, 2003). Pore-water samples were filtered in-line and acidified before analysis. The dissolved nutrient analyses, which were the focus of the study, required most of the volume from the pore-water samplers, which can hold no more than $60 \mathrm{~mL}$. After DOC analyses were completed, often less than $10 \mathrm{~mL}$ was available for ICP-MS analyses. Because each analytical replicate using the flow-injection method consumes at least $3 \mathrm{~mL}$ of sample, typically each pore-water sample reported only two replicates before exhausting the volume. Dilution to increase volume was not an option because lower concentration elements $(\mathrm{Cd}, \mathrm{Co}, \mathrm{Pb})$ would have been rendered undetectable. These volume limitations required that the method detection limits (MDL's) were reported higher for the pore-water samples than for the water-column samples.

\section{Acknowledgments}

The authors are grateful for critical logistical support from J. Chiu, and personnel from the U.S. Geological Survey (USGS) Western Ecological Research Center (WERC) in Vallejo, California. Thanks also go to Eric Mruz and Melisa Helton of the Don Edwards San Francisco Bay National Wildlife Refuge, for their project support. The U.S. Fish and Wildlife Service, 
USGS WERC in Vallejo, California, USGS San Francisco Bay Priority Ecosystems Study, and USGS Toxic Substances Hydrology Program are also acknowledged for support of this work.

\section{References Cited}

Berelson, W., McManus, J., Coale, K., Johnson, K., Burdige, D., Kilgore, T., Colodner, D., Chavez, F., Kudela, R., and Boucher, J., 2003, A time series of benthic flux measurements from Monterey Bay, CA: Continental Shelf Research, v. 23, p. 457-481

Boudreau, B.P., and Jorgensen, B.B., 2001, The benthic boundary layer, transport processes and biogeochemistry: New York, Oxford University Press, 404 p.

Buck K.N., Ross J.R., Flegal R.A., and Bruland K.W., 2007, A review of total dissolved copper and its chemical speciation in San Francisco Bay, California: Environmental Research, v. 105 p. 5-19.

Emerson S., Jahnke R., and Heggie D., 1984, Sediment-water exchange in shallow water estuarine sediments: Journal of Marine Research, v. 42, p. 709-730.

Fanning K.A., and Pilson M. E. Q., 1974, Diffusion of dissolved silica out of deep-sea sediments: Journal of Geophysical Research, v. 79, p. 1293-1297.

Franson, M.A.H., 1985, Standard methods for the examination of water and wastewater (16th ed.), Method 1003C.6: Washington, D.C., American Public Health Association, American Water Works Association, Water Pollution Control Federation, 1268 p.

Garret, K., 2012, Nutrient fluxes of a restored salt pond in San Francisco Bay: Whitman College, Wash., Senior honors thesis, 50 p.

Kuwabara, J.S., Davis, J.A., and Chang, C.C.Y., 1986, Algal growth response to particle-bound orthophosphate and zinc: Limnology and Oceanography, v. 31, p. 503-511.

Kuwabara, J.S., Chang, C.C.Y., Cloern, J.E., Fries, T.L., Davis, J.A., and Luoma, S.N., 1989, Trace metal associations in the water column of South San Francisco Bay, California: Estuarine Coastal and Shelf Science, v. 26, p. 307-325.

Kuwabara, J.S., Marvin-Dipasquale, M., Praskins, Wayne, Byron, Earl, Topping, B.R., Carter, J.L., Fend, S.V., Parchaso, Francis, and Krabbenhoft, D.P., 2002, Flux of dissolved forms of mercury across the sediment-water interface in Lahontan Reservoir, Nevada: U.S. Geological Survey Water Resources Investigations Report 02-4138, 48 p., http://water.usgs.gov/pubs/wri/wri024138/.

Kuwabara, J.S., Woods, P.F., Berelson, W.M., Balistrieri, L.S., Carter, J.L., Topping, B.R., and Fend, S.V., 2003, Importance of sediment-water interactions in Coeur d'Alene Lake, Idaho; management implications: Environmental Management, v. 32, p. 348-359.

Kuwabara, J.S., Topping, B.R., Moon, G.E., Husby, P., Lincoff, A., Carter, J.L., and Croteau, M.N., 2005, Mercury accumulation by lower trophic-level organisms in lentic systems within the Guadalupe River watershed, California: U.S. Geological Survey Scientific Investigations Report 2005-5037, 59 p., http://pubs.usgs.gov/sir/2005/5037.

Kuwabara, J.S., Lynch, D.D., Topping, B.R., Murphy, Fred, Carter, J.L., Simon, N.S., Parchaso, Francis, Wood, T.M., Lindenberg, M.K., Wiese, Katryn, and Avanzino, R.J., 2007, Quantifying the benthic source of dissolved nutrients to the water column of Upper Klamath Lake, Oregon: U.S. Geological Survey Open-File Report 2007-1276, 40 p.

http://pubs.usgs.gov/of/2007/1276/.

Kuwabara, J.S., Topping, B.R., Lynch, D.D., Carter, J.L., and Essaid, H.I., 2009, Benthic nutrient sources to hypereutrophic Upper Klamath Lake, Oregon: Environmental Toxicology and Chemistry, v. 28, p. 516-524. 
Li, Y-H, and Gregory, S., 1974, Diffusion of ions in seawater and in deep-sea sediments:

Geochimica et Cosmochimica Acta, v. 38, p. 703-714.

Life Science, Inc., 2003, South Bay Salt Ponds Initial Stewardship Plan, June 2003: Woodland, Calif., $251 \mathrm{p}$.

Marvin-DiPasquale, M., and Cox, M.H., 2007, Legacy mercury in Alviso Slough, South San Francisco Bay, California; concentration, speciation and mobility: U.S. Geological Survey Open-File Report 2007-1240, 99 p., http://pubs.usgs.gov/of/2007/1240/.

Mruz, E., Athearn, N.D., Henderson, K.D., and Takekawa, J.Y., 2009, 2008 self-monitoring program for Alviso ponds within South San Francisco Bay low salinity salt ponds: U.S. Fish and Wildlife Service, 146 p., accessed June 7, 2013, at http://southbayrestoration.org/monitoring/.

Parsons T.R., Maita Y., and Lalli, C.M., 1984, A manual of chemical and biological methods for seawater analysis: New York, Pergamon Press.

Qian, J.-G., and Mopper, K., 1996, Automated high-performance, high-temperature combustion total organic-carbon analyzer: Analytical Chemistry, v. 68, p. 3090-3097.

Thebault, J., Schraga, T.S., Cloern, J.E., and Dunlavey, E.G., 2008, Primary production and carrying capacity of former salt ponds after reconnection to San Francisco Bay: Wetlands, v. 28, p. 841-851.

Thompson, J.K., Nichols, F.H., and Wienke, S.M., 1981, Distribution of benthic chlorophyll in San Francisco Bay, California, February 1980-February 1981: U.S. Geological Survey Open-File Report 81-1134, 55 p.

Topping, B.R., Kuwabara, J.S., Parchaso, Francis, Hager, S.W., Arnsberg, A.J., and Murphy, F., 2001, Benthic flux of dissolved nickel into the water column of South San Francisco Bay:

U.S. Geological Survey Open-File Report 01-89, 50 p., http://pubs.water.usgs.gov/ofr01089/.

Topping, B.R. and Kuwabara, J.S., 2003, Dissolved nickel and benthic flux in South San Francisco Bay; a potential for natural sources to dominate: Bulletin of Environmental Toxicology and Chemistry, v. 71, p. 46-51.

Topping, B.R., Kuwabara, J.S., Marvin-DiPasquale, M.C., Agee, J.L, Kieu, L.H., Flanders, J.R., Parchaso, F., Hager, S.W., Lopez, C.B., and Krabbenhoft, D.P., 2004, Sediment remobilization of mercury in South San Francisco Bay, California: U.S. Geological Survey Scientific Investigations Report 2004-5196, 59 p., http://pubs.usgs.gov/sir/2004/5196/.

Topping, B.R., Kuwabara, J.S., Athearn, N.D., Takekawa, J.Y., Parchaso, F., Henderson, K.D., and Piotter, S., 2009, Benthic oxygen demand in three former salt ponds adjacent to south San Francisco Bay, California: U.S. Geological Survey Open-File Report 2009-1180, 21 p., http://pubs.usgs.gov/of/2009/1180/.

Vandenbruwane, J., De Neve, S., Qualls, R.G., Sleutel, S., and Hofman, G., 2007, Comparison of different isotherm models for dissolved organic carbon (DOC) and nitrogen (DON) sorption to mineral soil: Geoderma, v. 139, p. 144-153.

Wetzel, R.G., 2001, Limnology (3rd ed.): London, Academic Press, 1006 p. 


\section{Figures}

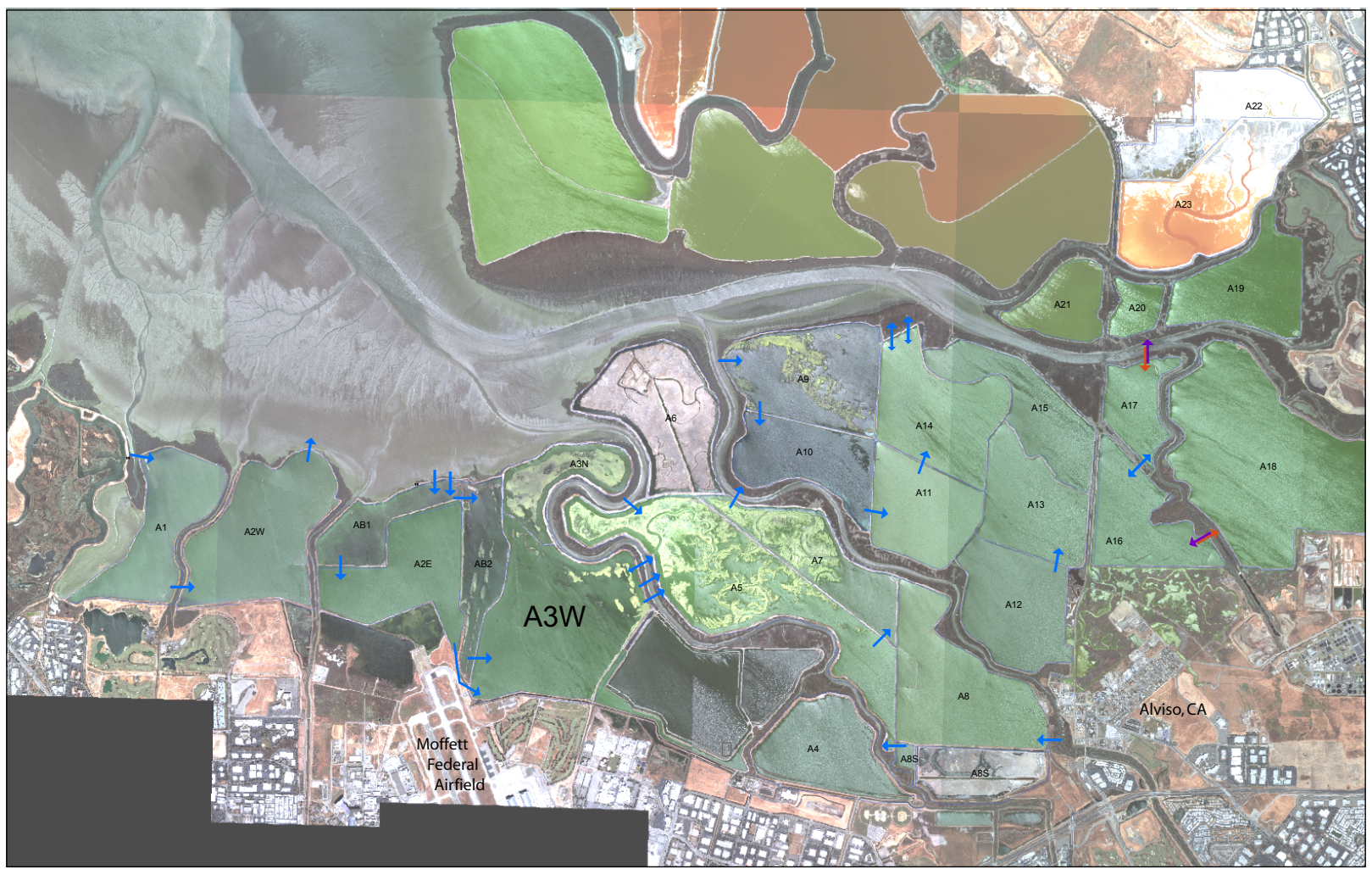

Figure 1. Satellite image of former salt ponds near Alviso, California, including flow direction between ponds. Blue arrows represent typical flow direction through structures that are often in use; note that two-way gates are rarely used in the smaller arrow direction. (Image and information courtesy of U.S. Army Corps of Engineers by way of Eric Mruz, Don Edwards San Francisco Bay National Wildlife Refuge.) 


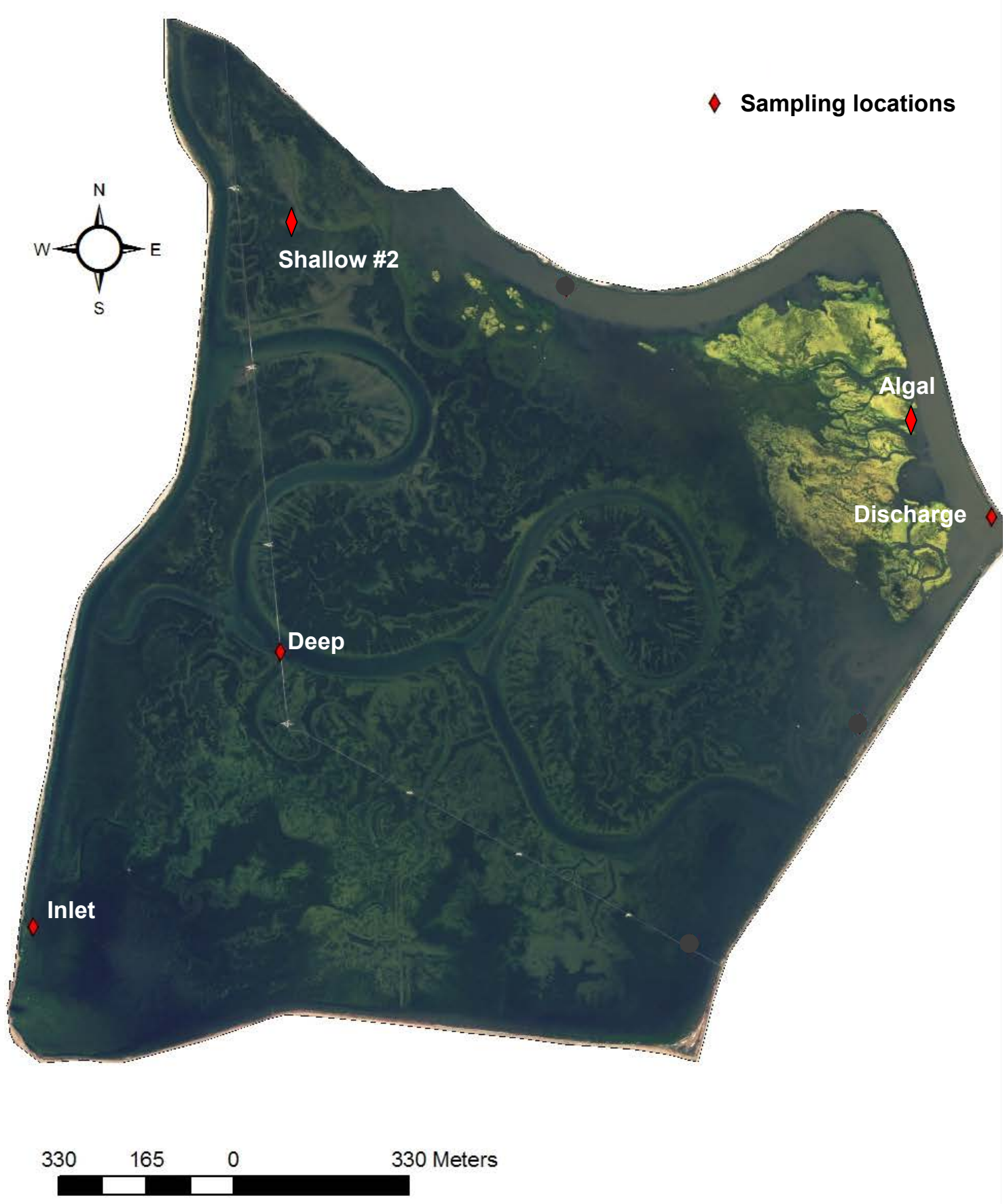

Figure 2. Satellite image of salt pond A3W near Alviso, California, with sampling locations. 


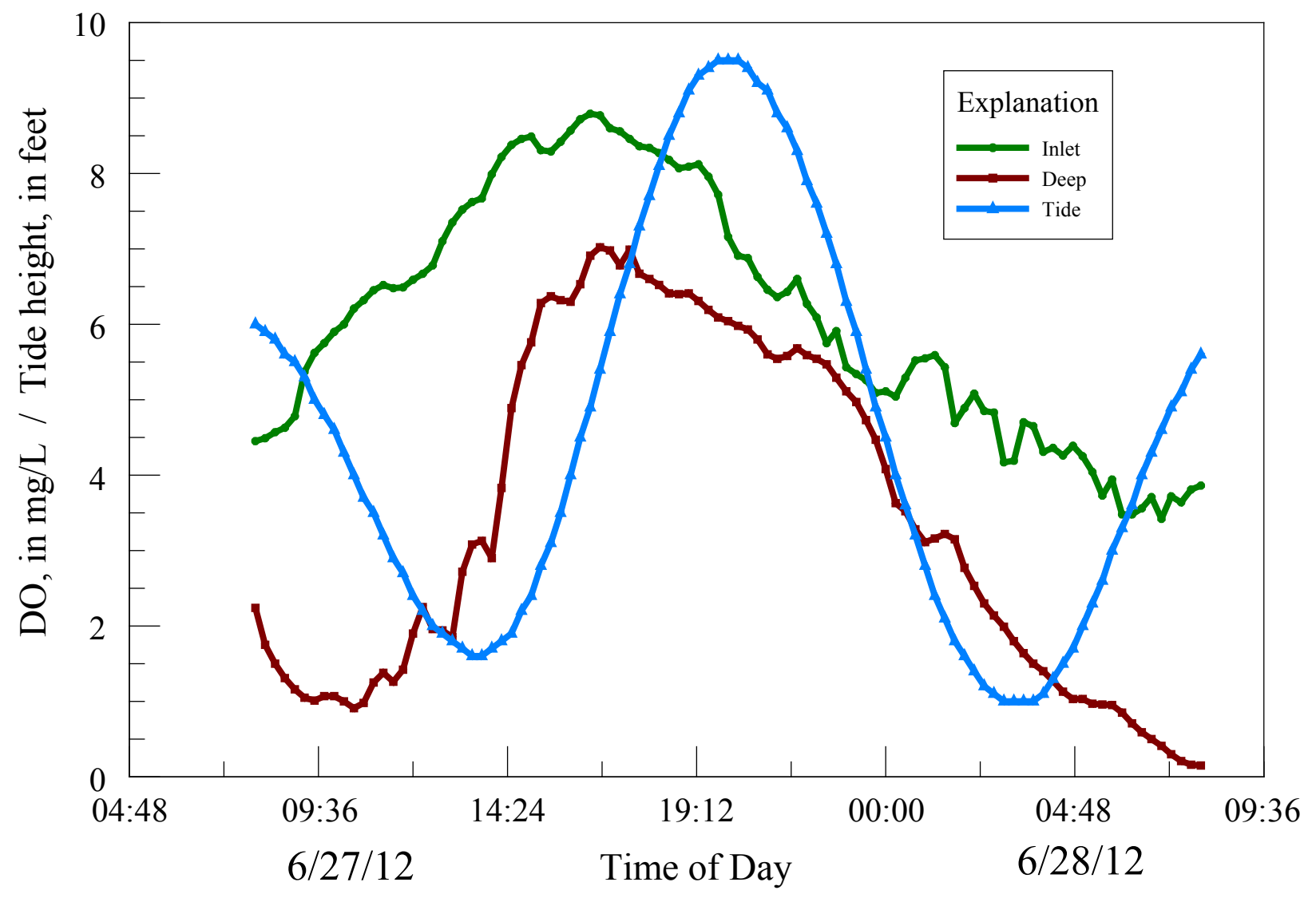

Figure 3. Plot of dissolved-oxygen (DO) in the water column for salt pond $\mathrm{A} 3 \mathrm{~W}$ as monitored by dataloggers during June 27-28, 2012, pore-water sampling. mg/L, milligrams per liter. 


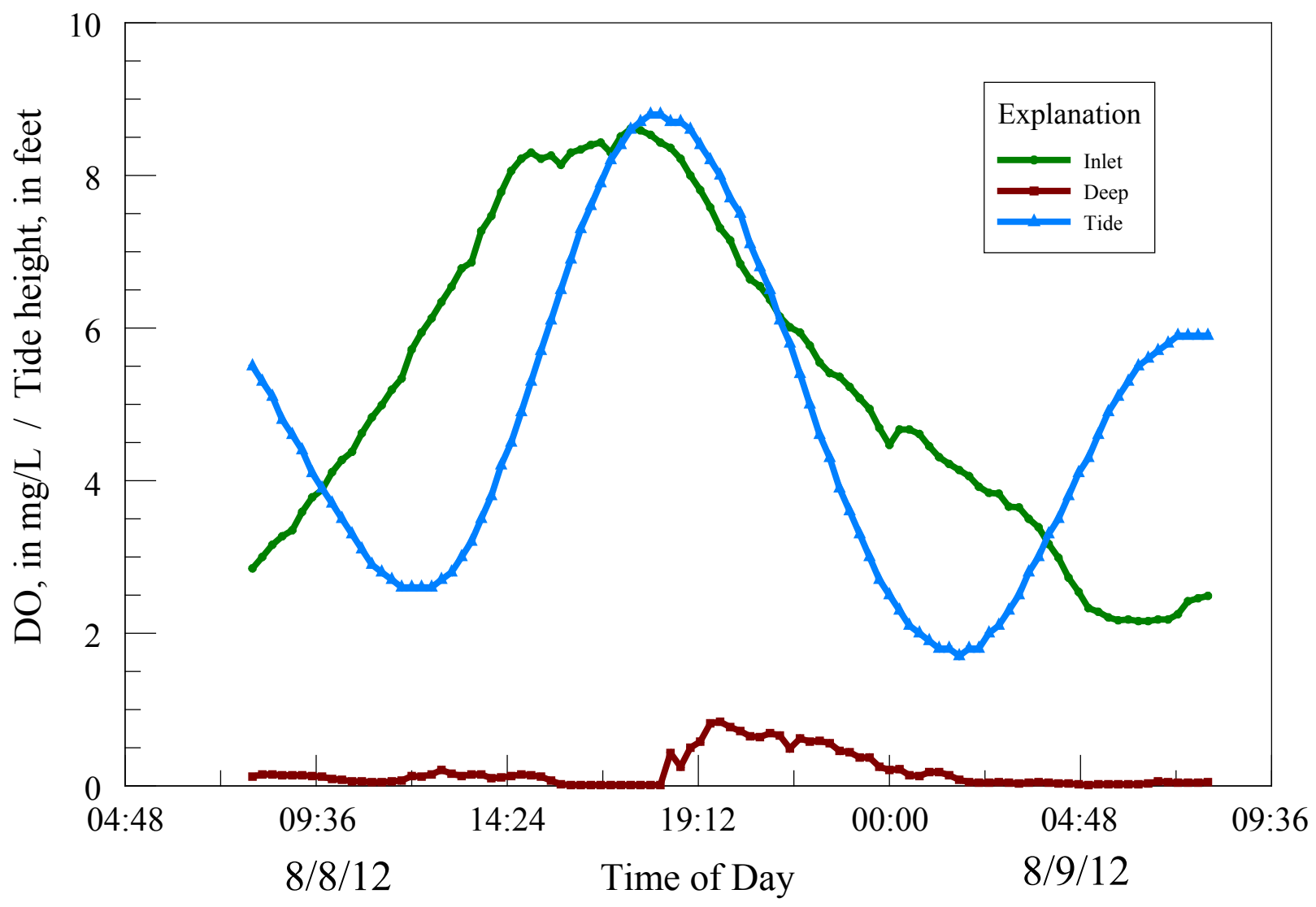

Figure 4. Plot of dissolved-oxygen (DO) in the water column for salt pond $\mathrm{A} 3 \mathrm{~W}$ as monitored by dataloggers during August 8-9, 2012, pore-water sampling. mg/L, milligrams per liter. 


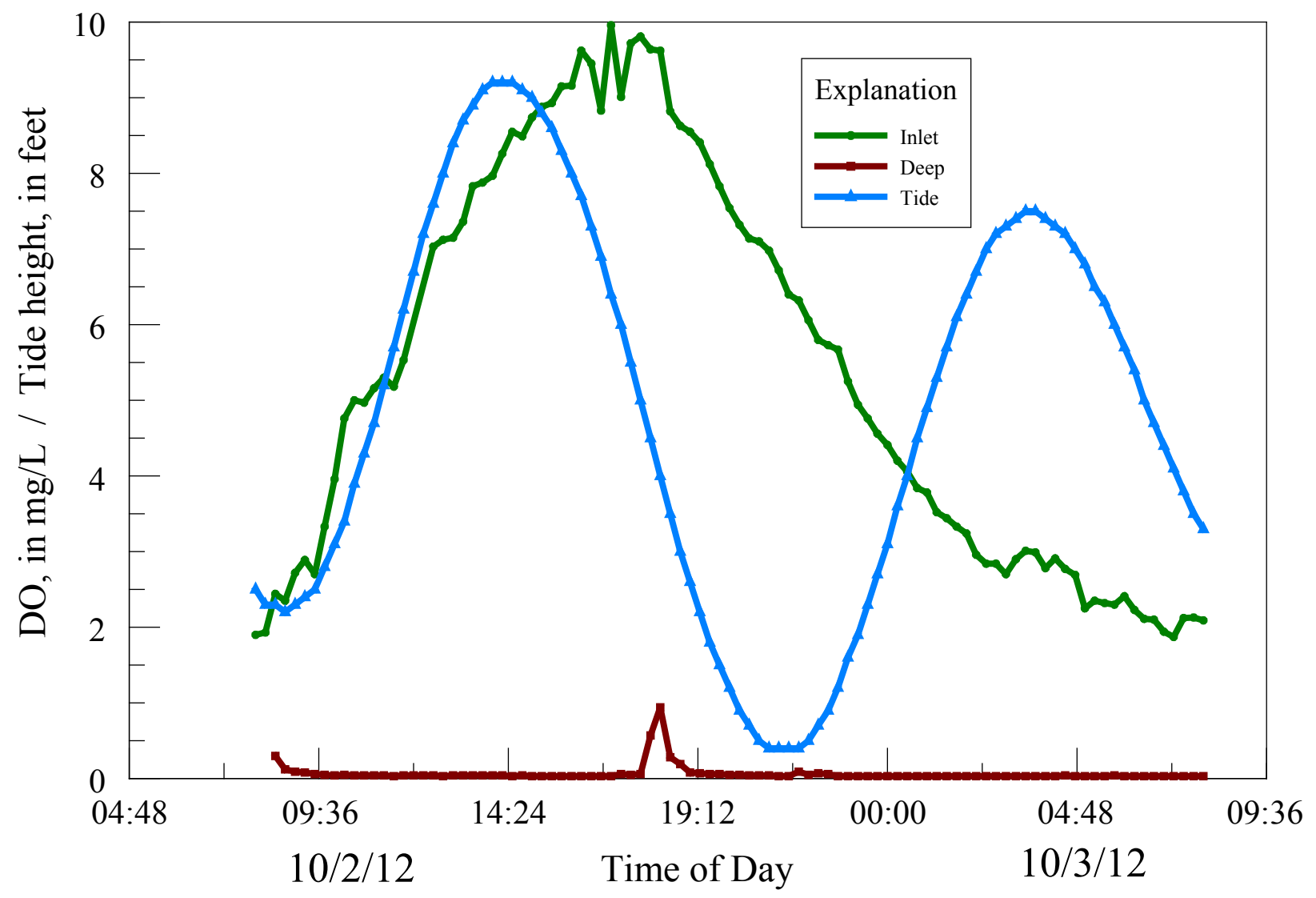

Figure 5. Plot of dissolved-oxygen (DO) in the water column for salt pond $\mathrm{A} 3 \mathrm{~W}$ as monitored by dataloggers during October 2-3, 2012, pore-water sampling. mg/L, milligrams per liter. 